\title{
The Effects of the Ozone Desizing and Combined Conventional Desizing and Scouring On Tear Strength and Abrasion Resistance of 100\% Cotton Terry Fabrics
}

Turhan $\mathrm{Y}^{1 *}$ and Soydas $\mathrm{S}^{2}$

${ }^{1}$ Department of Textile Engineering, Engineering Faculty, Pamukkale University, Kinikli, Denizli, Turkey

${ }^{2}$ Center of Research and Development, Yünsa Worsted and Woolen Production and Trading Co, Tekirdag, Turkey

\begin{abstract}
In this study, the effects of ozone desizing treatment on the water absorption and tear strength of $100 \%$ cotton terry fabrics were investigated and the results were compared with those obtained by combined conventional desizing and scouring treatment. For this purpose, ozone dose, ozonation time and pile yarn length were considered as the factors. Ozone desizing process was carried out for four different terry fabric having different pile yarn lengths at two different ozone dose (500 and $1000 \mathrm{~mL} /$ minute), four different ozonation time $(5,15,30,45$ minute). It was found that when the ozonation time or ozone dose increased the tear strength and abrasion resistance decreased, but the effect of ozone dose was remarkable on long ozonation duration. Also, it was determined that the combined conventional desizing and scouring process damaged the terry fabric much less than ozone desizing process.
\end{abstract}

Keywords: Ozone; Desizing; Tear strength; Abrasion resistance; Terry fabric

\section{Introduction}

Terry fabrics are produced by weaving or knitting. Woven terry fabrics have three different yarns. These are ground warp, ground weft and pile warp yarns. Ground warp and weft yarns form the basis of fabric structure and hold the pile yarn fixed. The yarns are generally made of hydrophilic fibers such as cotton, bamboo, linen because the aim of using terry fabrics is to dry the wet surfaces by absorbing the water or moisture. Because of the using purpose, the required properties for this fabric are a good water absorption, good abrasion resistance, good tear strength and soft handle. There are many studies researching the factors effecting on these properties. These studies are divided two groups consisting of the structural properties and finishing method $[1,2]$.

In the studies about the structural properties, the effects of the yarn type, fiber type, pile yarn length and pile warp/ground warp density on the properties of terry fabrics such as mechanical and absorptivity were investigated. Generally, in previous studies, bamboo and cotton pile yarns were examined to determine the effect of fiber type on abrasion resistance and the results were compared with each other. The weight loss was taken as basis to measure the abrasion resistance. It was seen that there was no difference between the abrasion resistance of terry fabrics with bamboo and cotton pile until a certain cycle, but after that cycle the weight loss of the terry fabric with bamboo pile was more than those of the terry fabric with cotton pile [3]. In a study, the effect of open-end (OE) and ring pile yarns on this resistance was investigated to found the effect of different yarn types. It was determined that the weight losses of all terry fabrics with ring pile yarn were lower than those of terry fabrics with OE pile yarn. Also it was observed that the weight loss of the terry fabric with OE pile yarn in wet case was lower than those of dry case [4]. The study about the effect of twist on flexural rigidity of the cotton terry fabric shown that the flexural rigidity of the fabric having twist less plie yarn was lower than that of the fabric having twisted pile yarn [5].

In the studies researching the effects of the fabric pre-treatments, the effects of pre-treatment processes such as desizing, scouring and bleaching on the mechanical properties of the cotton terry fabrics were investigated. In the studies, $100 \%$ cotton terry fabrics were scoured by using cellulose enzyme and alkaline enzyme. Later, the fabrics were bleached by hydrogen peroxide and peracetic acid (PAA). These studies shown that because the terry fabrics shrinked after alkaline scouring, the polymerization degree (fabric breaking strength) of the terry fabrics treated alkaline was higher than those of the terry fabrics treated enzyme $[6,7]$. It was seen in the abrasion test of the studies that the weight losses after alkaline scouring+peroxide bleaching processes were more than those of enzyme scouring+peroxide bleaching process, but the opposite result is obtained in terms of tensile strength. Also, it was found from these studies that there is not a significant difference between the abrasion resistances of terry fabrics treated by peroxide bleaching and PAA bleaching, but the breaking strength of terry fabrics treated PAA bleaching was higher than those of terry fabrics treated by peroxide [7].

In the studies about the effect of ozone pretreatment process on the fabric properties, the effects of the ozone desizing, scouring and bleaching process on the water absorption and mechanical properties of the cotton plain fabrics were investigated. While on some of these studies ozone was applied to the fabric alone for bleaching and scouring, it was applied with together ultraviolet energy (UV), ultrasound energy (US), some enzymes, additives and conventional methods on the other of studies. For ozonation process, ozonation time, ozone dose, ph value, temperature and water pick up rate of cotton fabric were considered as the factor. It was found that when the ozonation duration for the ozone bleaching process increased, the polymerization degree and the breaking strength of the fabric decreased, but this decline was less than

*Corresponding author: Turhan Y, Department of Textile Engineering, Engineering Faculty, Pamukkale University, Kinikli, Denizli, Turkey, Tel:+90-5052154482; E-mail: yturhan@pau.edu.tr

Received April 03, 2018; Accepted April 11, 2018; Published April 19, 2018

Citation: Turhan Y, Soydas S (2018) The Effects of the Ozone Desizing and Combined Conventional Desizing and Scouring On Tear Strength and Abrasion Resistance of $100 \%$ Cotton Terry Fabrics. J Textile Sci Eng 8: 353. doi: 10.4172/2165-8064.1000353

Copyright: (C) 2018 Turhan $\mathrm{Y}$, et al. This is an open-access article distributed under the terms of the Creative Commons Attribution License, which permits unrestricted use, distribution, and reproduction in any medium, provided the original author and source are credited. 
Citation: Turhan Y, Soydas S (2018) The Effects of the Ozone Desizing and Combined Conventional Desizing and Scouring On Tear Strength and Abrasion Resistance of 100\% Cotton Terry Fabrics. J Textile Sci Eng 8: 353. doi: 10.4172/2165-8064.1000353

Page 2 of 7

those of conventional bleaching (hydrogen peroxide) [8-14]. In one of these investigations, it was determined that the increase of the ozonation duration caused the weight loss of fabric to increase. As comparing the results with conventional bleaching, it was seen that also the weight loss increased after the peroxide bleaching, but this increasing was lower than those of ozone bleaching process [11]. The studies researching the effect of ozone dose and $\mathrm{pH}$ value during ozone bleaching shown that when the ozone dose increased, the bursting and breaking strength of cotton plain fabric decreased, but the effect of ozone dose was more remarkable in the case of more ozonation durations $[10,12,14]$. The researches reached the result that the low ph values (namely acidic conditions) decreased the breaking strength and so the most suitable condition for ozonation without damaging the cotton fabric was neutral value of $\mathrm{pH}[10,11,13]$. In some previous studies, the bleaching of cotton plain fabrics was carried out by combination of ozone+UV, ozone+US, ozone $+\mathrm{UV}+\mathrm{US}$ and ozone+peroxide bleaching. These investigations found that the maximum loss of breaking strength happened on the case of the ozone+peroxide combination[15] and UV+US+ozone combination[16], but the minimum loss of strength was achieved by using ozone and UV alone[16].

When the previous studies are generally evaluated, the lack of work on the effects of pretreatment processes such as ozone bleaching or desizing on the properties of the terry fabrics draws attention. These studies focused on mostly plain cotton fabrics to investigate the effect of ozone. Terry fabrics are made of cotton yarns such as cotton plain fabric, but they have pile yarn on both side and they are different in terms as structural from the plain fabric. So, they may react differently to ozone pre-finishing process. In this study, the effects of ozone desizing treatment on tear strength and abrasion resistance of the terry fabrics are investigated and the results are compared with combined conventional desizing and scouring. The study is original because of two reasons. The first reason is to use ozonation process for desizing pre-treatment of a terry fabric; the other is to apply combination of conventional desizing and scouring to the cotton fabrics.

\section{Material and Method Material}

The materials used in this study are four grouped under heading. They are

1) Terry fabric samples

2) Ozone application equipment

3) Chemicals

4) Testing devices.

\section{Terry fabric samples}

The terry fabrics used in the study have piles on both two sides. The properties of yarn forming the fabric and the properties of fabric are shown in Table 1 and Table 2, respectively [17] (Tables 1 and 2) (Figure 1).

\section{Ozone application equipment}

Ozone application equipment consists of four main devices. They are

\begin{tabular}{|c|c|c|c|c|}
\hline Yarn Group & Yarn Type & Fiber Type & $\begin{array}{c}\text { Yarn Number } \\
\text { (Ne) }\end{array}$ & Yarn Density \\
\hline Pile Warp Yarn & Ring, Carded & $\% 100$ Cotton & $16 / 1$ & 13 end/cm \\
\hline Weft Yarn & Ring, Carded & $\% 100$ Cotton & $16 / 1$ & $17 \mathrm{pick} / \mathrm{cm}$ \\
\hline Ground Warp Yarn & Ring, Carded & $\% 100$ Cotton & $20 / 2$ & $13 \mathrm{end} / \mathrm{cm}$ \\
\hline
\end{tabular}

Table 1: The properties of yarn.

\begin{tabular}{|c|c|c|}
\hline Fabric areal weight $\mathbf{( g r / \mathbf { m } ^ { 2 } )}$ & $\begin{array}{c}\text { Pile Yarn Length } \\
(\mathbf{c m} / \mathbf{1 0} \mathbf{~ c m})\end{array}$ & Presence of pile \\
\hline 350 & 43,63 & on both side of fabric \\
\hline 400 & 53,45 & on both side of fabric \\
\hline 450 & 67,66 & on both side of fabric \\
\hline 500 & 76,15 & on both side of fabric \\
\hline
\end{tabular}

Table 2: The properties of fabric.

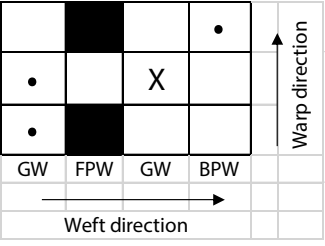

(a) Unit weave of terry fabric.

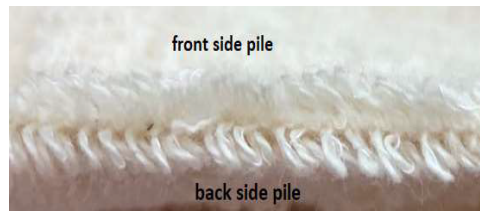

(b) Cross section image of terry fabric
Figure 1: Unit weave of terry fabric and cross section image of terry fabric. (GW: ground warp; FPW: face pile warp; BPW: back pile warp
1) Oxygen supplier
2) Ozone generator
3) Ozone flow meter
4) Ozone application chamber

Figure 2 shows all of the ozone application equipment. The application of ozone to the fabric was carried out in a glass chamber [17].

The volume of the chamber: $140 \mathrm{~mL}$

The radius of the chamber: $27 \mathrm{~mm}$.

Ozone application chamber is shown in Following below Figure 3.

\section{Chemicals and additives}

For combined desizing and scouring process:

- Alpha-amylase enzyme

- $\quad$ Pectinaze enzyme (for scouring treatment)

- Dispergator

- $\quad$ Ion holder

\section{Test devices}

Two test devices are used in this study. These are devices for measuring tearing strength and abrasion resistance test.

James H Heal Elmatear Digital Tear Tester (Elmandorf) trademark device was used to measure the tearing strength of terry fabric samples. Martindale trademark device was used to determine abrasion resistance of terry fabrics. Figure 4 and Figure 5 show tearing test and abrasion resistance test devices respectively [17].

\section{Method}

The process flow in the study is shown as schema in the following figure below (Figure 6) [17].

\section{Ozone desizing processes}

Ozone desizing was carried out by using ozone equipment. The size of terry fabric samples is $13 \times 21 \mathrm{~cm}$. Water pick up rate of fabrics and 


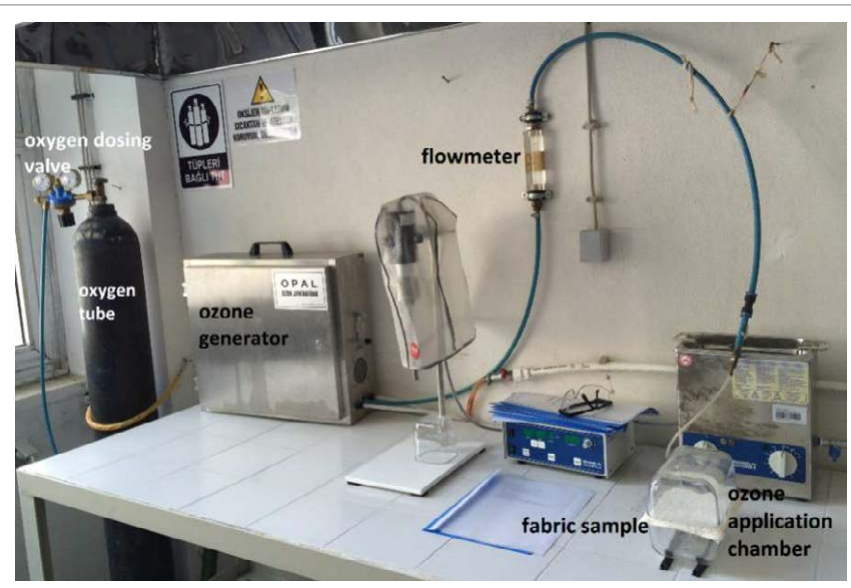

Figure 2: Ozone application equipment.

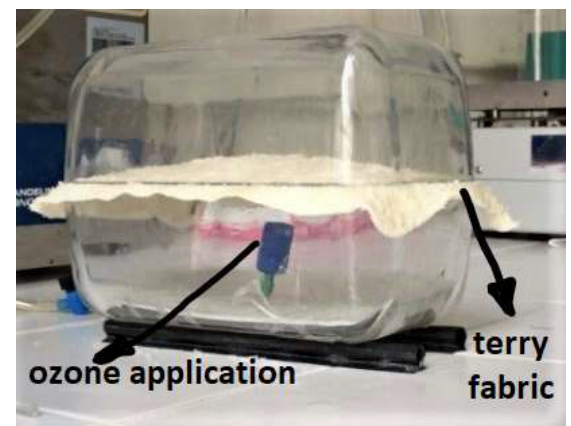

Figure 3: Ozone application chamber.

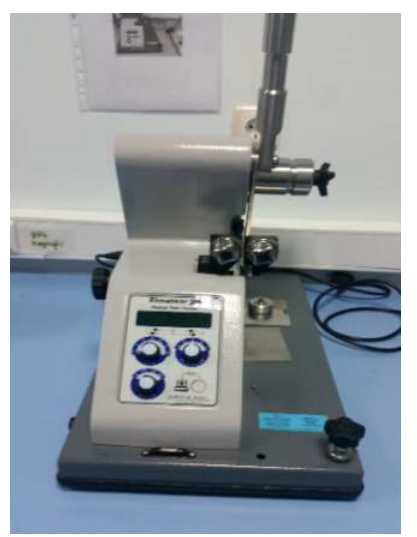

Figure 4: Fabric tearing strength test device.

$\mathrm{PH}$ value are determined taking into account the values recommended in previous studies in this subject. All of ozonation process is performed room temperature (approximate $20^{\circ} \mathrm{C}$ ).

The method of ozone application to the samples is presented in tabular form below (Table 3) [17].

\section{Combined conventional desizing and scouring process $(\mathrm{CCM})$}

In the study, the chemical component containing the enzymes alpha-amylase and pectinase was used. This trademark of chemical is

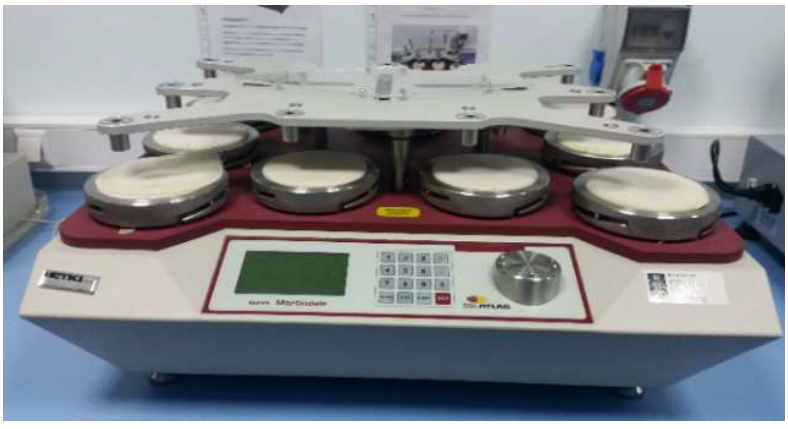

Figure 5: Test device for abrasion resistance.

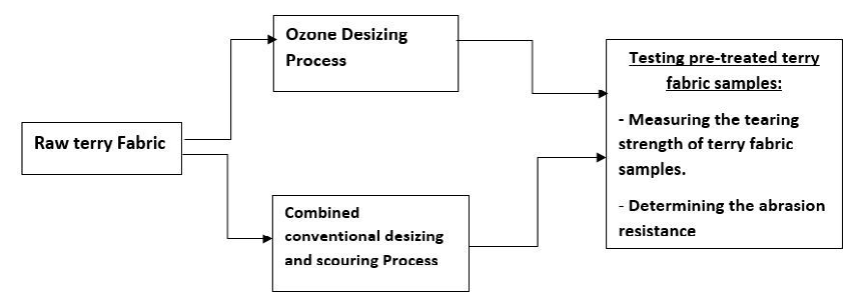

Figure 6: The process flow in the study

TANA $^{\circ}$ ZYM NCP and the properties is presented following $[17,18]$ :

- Chemical structure: Water-based enzyme including nonionic surfactants (surface active agents) preparations

- $\quad$ Appearance: Misty brown liquid

- The density $\left(20^{\circ} \mathrm{C}\right)$ is about $1.0 \mathrm{~g} / \mathrm{cm}^{3}$

- Viscosity $\left(\mathbf{2 0}^{\circ} \mathrm{C}\right)$ : Approx. $200 \mathrm{mPa} . \mathrm{s}$

- $\quad \mathrm{pH}\left(20^{\circ} \mathrm{C}\right): 6-8$

- $\quad$-Stability pH: 6.0 - 9.5

- Dissolution can be diluted with cold water

Process recipe is as follow [17]:

The rate of the flotte: $1: 20$

Process is performed as following order:

Step 1: Terry fabric sample is treated with $1.5 \%$ enzyme for 15 minutes at 60 degrees (to provide $80-90 \%$ impregnation).

Step 2: Waiting $10 \mathrm{~min}$.

Step 3: Washing for $5 \mathrm{~min}$. at $95^{\circ} \mathrm{C}$

Step 4: Terry fabric is treated with $1.5 \mathrm{ml} / \mathrm{l}$ dispersing agent /ion holder for $15 \mathrm{~min}$. at $60^{\circ} \mathrm{C}$

Step 5: Rinsing under running water.

Desizing efficiency was determined by dripping I2/KI solution onto the different areas of terry fabric samples and by comparing the color changing on the surface of the samples with the Tegewa Scale (TS) [17].

\section{Testing method of tearing strength}

The standard of ISO 13937-1 (Ballistic pendulum method) was taken as reference to testing the tear strength of the samples. The tear strength of warp (tear strength in weft direction) was tested because the 
Citation: Turhan Y, Soydas S (2018) The Effects of the Ozone Desizing and Combined Conventional Desizing and Scouring On Tear Strength and Abrasion Resistance of 100\% Cotton Terry Fabrics. J Textile Sci Eng 8: 353. doi: 10.4172/2165-8064.1000353

Page 4 of 7

\begin{tabular}{|c|c|c|c|c|c|c|}
\hline $\begin{array}{c}\text { Sample } \\
\text { No. }\end{array}$ & $\begin{array}{c}\text { Fabric areal } \\
\text { weight } \\
\left(\mathrm{g} / \mathrm{m}^{2}\right)\end{array}$ & $\begin{array}{l}\text { Pile length/ } \\
10 \mathrm{~cm} \\
(\mathrm{~cm} / 10 \mathrm{~cm})\end{array}$ & PH & $\begin{array}{c}\text { water pick } \\
\text { up amount } \\
(\%)\end{array}$ & $\begin{array}{c}\text { Ozone } \\
\text { Dose } \\
\text { (ml/min.) }\end{array}$ & $\begin{array}{c}\text { Ozonation } \\
\text { Duration } \\
\text { (min.) }\end{array}$ \\
\hline A1-1 & 350 & \multirow{8}{*}{43,63} & \multirow{8}{*}{6} & \multirow{8}{*}{40} & 500 & 5 \\
\hline A1-2 & 350 & & & & 500 & 15 \\
\hline A1-3 & 350 & & & & 500 & 30 \\
\hline A1-4 & 350 & & & & 500 & 45 \\
\hline A2-1 & 350 & & & & 1000 & 5 \\
\hline A2-2 & 350 & & & & 1000 & 15 \\
\hline A2-3 & 350 & & & & 1000 & 30 \\
\hline A2-4 & 350 & & & & 1000 & 45 \\
\hline B1-1 & 400 & \multirow{8}{*}{53,45} & \multirow{8}{*}{6} & \multirow{8}{*}{40} & 500 & 5 \\
\hline B1-2 & 400 & & & & 500 & 15 \\
\hline B1-3 & 400 & & & & 500 & 30 \\
\hline B1-4 & 400 & & & & 500 & 45 \\
\hline B2-1 & 400 & & & & 1000 & 5 \\
\hline B2-2 & 400 & & & & 1000 & 15 \\
\hline B2-3 & 400 & & & & 1000 & 30 \\
\hline B2-4 & 400 & & & & 1000 & 45 \\
\hline C1-1 & 450 & \multirow{8}{*}{67,66} & \multirow{8}{*}{6} & \multirow{8}{*}{40} & 500 & 5 \\
\hline C1-2 & 450 & & & & 500 & 15 \\
\hline C1-3 & 450 & & & & 500 & 30 \\
\hline C1-4 & 450 & & & & 500 & 45 \\
\hline C2-1 & 450 & & & & 1000 & 5 \\
\hline C2-2 & 450 & & & & 1000 & 15 \\
\hline C2-3 & 450 & & & & 1000 & 30 \\
\hline C2-4 & 450 & & & & 1000 & 45 \\
\hline D1-1 & 500 & \multirow{8}{*}{76,15} & \multirow{8}{*}{6} & \multirow{8}{*}{40} & 500 & 5 \\
\hline D1-2 & 500 & & & & 500 & 15 \\
\hline D1-3 & 500 & & & & 500 & 30 \\
\hline D1-4 & 500 & & & & 500 & 45 \\
\hline D2-1 & 500 & & & & 1000 & 5 \\
\hline D2-2 & 500 & & & & 1000 & 15 \\
\hline D2-3 & 500 & & & & 1000 & 30 \\
\hline D2-4 & 500 & & & & 1000 & 45 \\
\hline
\end{tabular}

Table 3: The method of ozone application to the terry fabric samples.

fabrics have same weft density and weft yarn type, namely there is no differences in terms of weft properties of fabric samples. Besides, fabrics have pile warp yarns on both of their surfaces and the pile lengths are different for all samples. During ozonation, the pile yarn is in contact and effected by ozone. For these reasons, it was aimed to examine the tear strength of warp (tear strength in weft direction) [17].

\section{Testing method of abrasion resistance}

ASTM D4966-98 Standard was taken as reference to testing abrasion resistance of terry fabric samples. The abrasion resistance was determined by detecting the weight losses for the certain abrasion cycles. The test was applied until the cycle leading to breaking on the surface of fabric [17]. The weight loss was calculated as follow:

\section{$\mathrm{WL}=(\mathrm{W} 1-\mathrm{WA})$}

Where,

W1: The weight of untested fabric (gr)

WA: weight of fabric subjected to abrasion test (gr) WL: Weight loss (gr).

\section{Result and Discussion}

\section{Evaluating of the tear strength results}

Tear strength values are evaluated in terms of the pile lengths, ozonation durations and the desizing methods (combined conventional desizing and ozone desizing method). Figures 7-10 compare the results of tear strength belonging to respectively, $350 \mathrm{~g} / \mathrm{m}^{2}, 400 \mathrm{~g} / \mathrm{m}^{2}, 450 \mathrm{~g} /$ $\mathrm{m}^{2}$ and $500 \mathrm{~g} / \mathrm{m}^{2}$ areal weight of terry fabric with those of combined conventional desizing and scouring method [17].

By comparing and evaluating the figures, the following results are deduced:

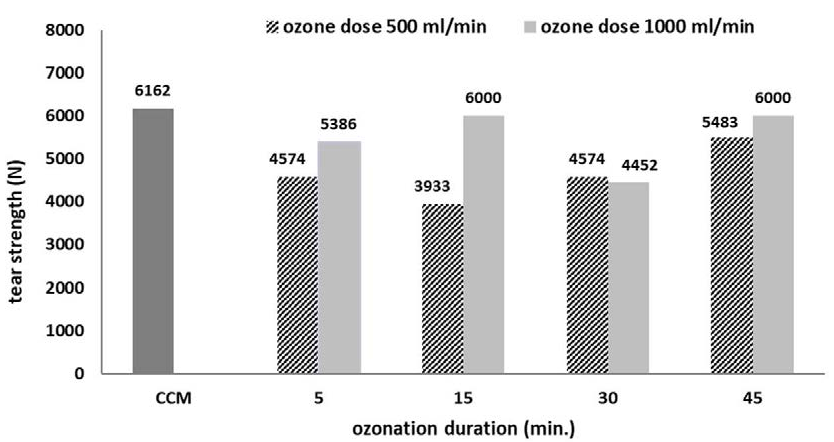

Figure 7: Tear strength of fabric having $350 \mathrm{gr} / \mathrm{m}^{2}$ areal weight. (CCM: Combined conventional desizing and scouring method)

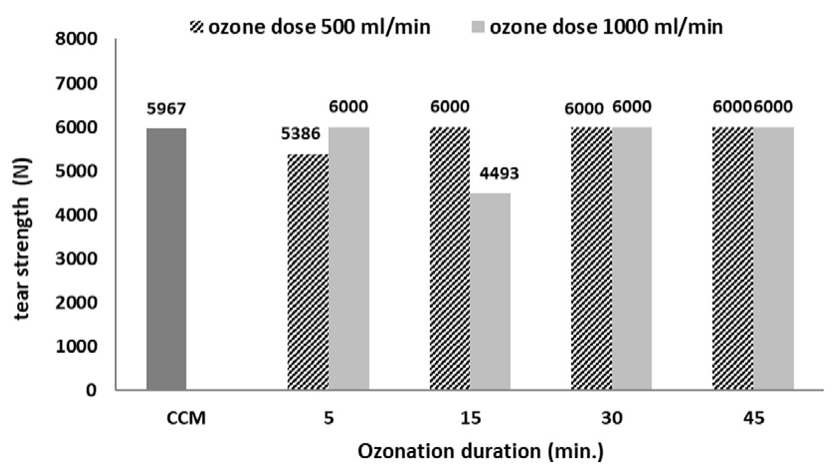

Figure 8: Tear strength of fabric having $400 \mathrm{gr} / \mathrm{m}^{2}$ areal weight (CCM: Combined conventional desizing and scouring method).

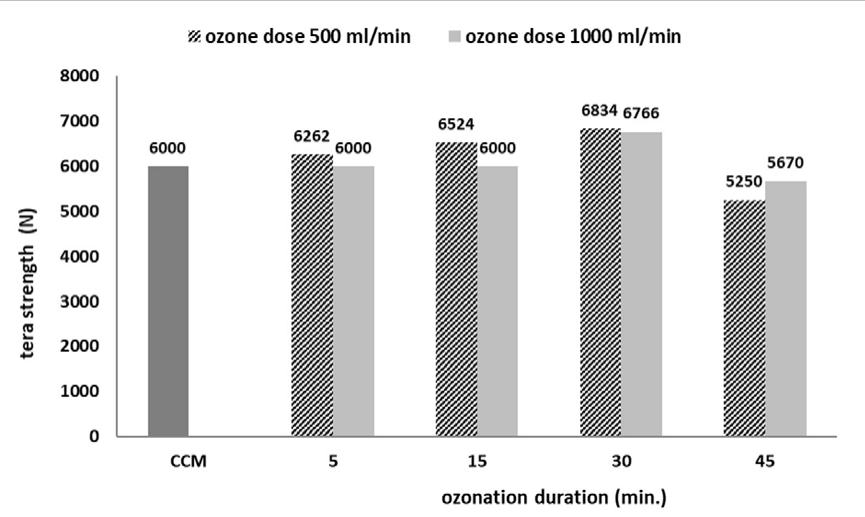

Figure 9: Tear strength of fabric having $450 \mathrm{gr} / \mathrm{m}^{2}$ areal weight. (CCM: Combined conventional desizing and scouring method). 
Citation: Turhan Y, Soydas S (2018) The Effects of the Ozone Desizing and Combined Conventional Desizing and Scouring On Tear Strength and Abrasion Resistance of 100\% Cotton Terry Fabrics. J Textile Sci Eng 8: 353. doi: 10.4172/2165-8064.1000353

Page 5 of 7

After the process of ozone desizing, it is seen that for short pile length fabric such as the terry fabric having $350 \mathrm{~g} / \mathrm{m}^{2}$ areal weight, the tear strength values of terry fabric treated by low ozone dose are lower than those of the terry fabrics treated by high ozone dose for all ozonation duration.

Also the figures show clearly that in the short pile length fabric, when the ozonation duration increases, the tear strength of terry fabric decreases until a certain duration. However, in the case of longer pile length fabric, it is seen that there is no remarkable difference between the tear strength values of both the pile lengths. Additionally, it can be stated the result that the tear strength values of shortest pile length fabric are lower than those of the other fabrics.

- Comparing the process of the combined conventional desizing and scouring (CCM) with the ozone desizing method, it is concluded that the tear strength values of terry fabrics applied CCM are higher than those of the fabric having shortest pile length, but are lower than those of the fabrics having longer pile lengths.

- $\quad$ After the process of the combined conventional desizing and scouring method (CCM), it is seen that the tear strength of the terry fabric having the shortest pile length is higher than those of the fabric having longer pile lengths.

- From the figures, it is observed that in the both of the desizing method, the tear strength values of terry fabrics having the shorter pile yarn length are higher than those of the fabrics having longer pile yarn length.

\section{Evaluating of the abrasion resistance results}

Abrasion tests for all samples were performed for ten different cycles, namely 500,1000, 5000, 10000, 15000, 20000, 25000, 30000, 35000,40000 . In this study, the terry fabric treated ozone desizing and combined conventional desizing process were examined for determining the abrasion resistance.

The abrasion resistance results of the terry fabrics treated ozone desizing method are shown in the following table below [17] (Table 4).

\section{Evaluating the table}

- It is seen that the weight losses of all terry fabrics increase when the ozonation duration and dose increase,

- It is determined that while the breaking of the terry fabrics with short pile length treated by low ozone dose occurs in the short cycle (namely $350 \mathrm{~g} / \mathrm{m}^{2}$ and $400 \mathrm{~g} / \mathrm{m}^{2}$ ), the breaking of the fabrics with long pile length treated by high ozone dose takes place in longer cycles (namely $450 \mathrm{~g} / \mathrm{m}^{2}$ ).

- Additionally, it is seen that in same abrasion cycles and same

\begin{tabular}{|c|c|c|c|c|c|c|c|c|c|c|c|c|c|}
\hline \multirow{2}{*}{$\begin{array}{l}\text { Fabric areal weigth } \\
\left(\mathrm{gr} / \mathrm{m}^{2}\right)\end{array}$} & \multirow{2}{*}{$\begin{array}{l}\text { Pile yarn length } \\
(\mathrm{cm} / 10 \mathrm{~cm})\end{array}$} & \multirow{2}{*}{$\begin{array}{l}\text { Ozone dose } \\
(\mathrm{ml} / \mathrm{l})\end{array}$} & \multirow{2}{*}{$\begin{array}{l}\text { Ozonation } \\
\text { duration (minute) }\end{array}$} & \multicolumn{10}{|c|}{ weight losses for different cycles of abrasion test (gr) } \\
\hline & & & & 1000 & 5000 & 10000 & 15000 & 20000 & 25000 & 30000 & 35000 & 40000 & 450000 \\
\hline \multirow{8}{*}{350} & \multirow{8}{*}{43.63} & 500 & 5 & 0 & 0.02 & 0.04 & 0.07 & 0.1 & 0.12 & 0.15 & 0.17 & * & \\
\hline & & 500 & 15 & 0 & 0.02 & 0.05 & 0.08 & 0.11 & 0.13 & 0.16 & 0.19 & * & \\
\hline & & 500 & 30 & 0 & 0.01 & 0.03 & 0.06 & 0.1 & 0.13 & 0.17 & 0.21 & * & \\
\hline & & 500 & 45 & 0 & 0.02 & 0.04 & 0.08 & 0.12 & 0.15 & 0.19 & 0.23 & * & \\
\hline & & 1000 & 5 & 0 & 0 & 0 & 0.01 & 0.02 & 0.06 & * & & & \\
\hline & & 1000 & 15 & 0 & 0.02 & 0.06 & 0.1 & 0.14 & 0.18 & * & & & \\
\hline & & 1000 & 30 & 0 & 0.02 & 0.05 & 0.13 & * & & & & & \\
\hline & & 1000 & 45 & 0 & 0.01 & 0.04 & 0.1 & 0.18 & * & & & & \\
\hline \multirow{8}{*}{400} & \multirow{8}{*}{53.45} & 500 & 5 & 0 & 0.01 & 0.03 & 0.06 & 0.09 & 0.12 & 0.13 & 0.13 & 0.13 & 0.15 \\
\hline & & 500 & 15 & 0 & 0.02 & 0.04 & 0.07 & 0.09 & 0.11 & 0.13 & 0.15 & 0.18 & 0.2 \\
\hline & & 500 & 30 & 0 & 0.01 & 0.02 & 0.04 & 0.05 & 0.08 & 0.1 & 0.14 & 0.16 & 0.19 \\
\hline & & 500 & 45 & 0 & 0.01 & 0.02 & 0.06 & 0.09 & 0.12 & 0.13 & 0.16 & 0.23 & \\
\hline & & 1000 & 5 & 0.0008 & 0.01 & 0.03 & 0.06 & 0.09 & 0.12 & * & & & \\
\hline & & 1000 & 15 & 0.0008 & 0.01 & 0.03 & 0.05 & 0.07 & 0.18 & * & & & \\
\hline & & 1000 & 30 & 0.0008 & 0.02 & 0.04 & 0.07 & 0.09 & 0.21 & * & & & \\
\hline & & 1000 & 45 & 0.0008 & 0.02 & 0.04 & 0.09 & 0.13 & 0.25 & * & & & \\
\hline \multirow{8}{*}{450} & \multirow{8}{*}{67.66} & 500 & 5 & 0.0008 & 0.01 & 0.03 & 0.06 & * & & & & & \\
\hline & & 500 & 15 & 0.0008 & 0 & 0 & 0.01 & * & & & & & \\
\hline & & 500 & 30 & 0.0008 & 0.02 & 0.16 & 0.36 & * & & & & & \\
\hline & & 500 & 45 & 0.0008 & 0.16 & 0.35 & * & & & & & & \\
\hline & & 1000 & 5 & 0.0008 & 0.02 & 0.04 & 0.06 & 0.08 & 0.1 & 0.12 & * & & \\
\hline & & 1000 & 15 & 0.0008 & 0.03 & 0.06 & 0.09 & 0.13 & 0.19 & 0.36 & * & & \\
\hline & & 1000 & 30 & 0.0008 & 0.02 & 0.06 & 0.1 & 0.15 & 0.3 & 0.49 & * & & \\
\hline & & 1000 & 45 & 0.0008 & 0.02 & 0.07 & 0.12 & 0.18 & 0.24 & 0.27 & * & & \\
\hline \multirow{8}{*}{500} & \multirow{8}{*}{76.15} & 500 & 5 & 0.0008 & 0.02 & 0.05 & 0.08 & 0.12 & 0.15 & 0.17 & 0.2 & 0.23 & 0.26 \\
\hline & & 500 & 15 & 0.001 & 0.02 & 0.04 & 0.07 & 0.11 & 0.14 & 0.18 & 0.22 & 0.27 & 0.37 \\
\hline & & 500 & 30 & 0.001 & 0.02 & 0.04 & 0.08 & 0.26 & * & & & & \\
\hline & & 500 & 45 & 0.001 & 0.04 & 0.08 & 0.13 & 0.19 & 0.23 & 0.27 & 0.32 & 0.38 & 0.43 \\
\hline & & 1000 & 5 & 0.001 & 0.02 & 0.05 & 0.09 & 0.13 & 0.15 & 0.17 & 0.19 & 0.22 & 0.25 \\
\hline & & 1000 & 15 & 0.001 & 0.01 & 0.03 & 0.05 & 0.07 & 0.09 & 0.11 & 0.14 & 0.18 & 0.22 \\
\hline & & 1000 & 30 & 0.001 & 0.02 & 0.06 & 0.1 & 0.15 & 0.19 & 0.23 & 0.27 & 0.32 & 0.37 \\
\hline & & 1000 & 45 & 0.001 & 0.01 & 0.06 & 0.11 & 0.17 & 0.23 & 0.26 & 0.3 & 0.34 & 0.39 \\
\hline
\end{tabular}

( $*$ The cycle causing the breaking of terry fabric and the removing of pile) after abrasion test.

Table 4: The weight losses of the terry fabrics treated by ozone desizing process. 
Citation: Turhan Y, Soydas S (2018) The Effects of the Ozone Desizing and Combined Conventional Desizing and Scouring On Tear Strength and Abrasion Resistance of 100\% Cotton Terry Fabrics. J Textile Sci Eng 8: 353. doi: 10.4172/2165-8064.1000353

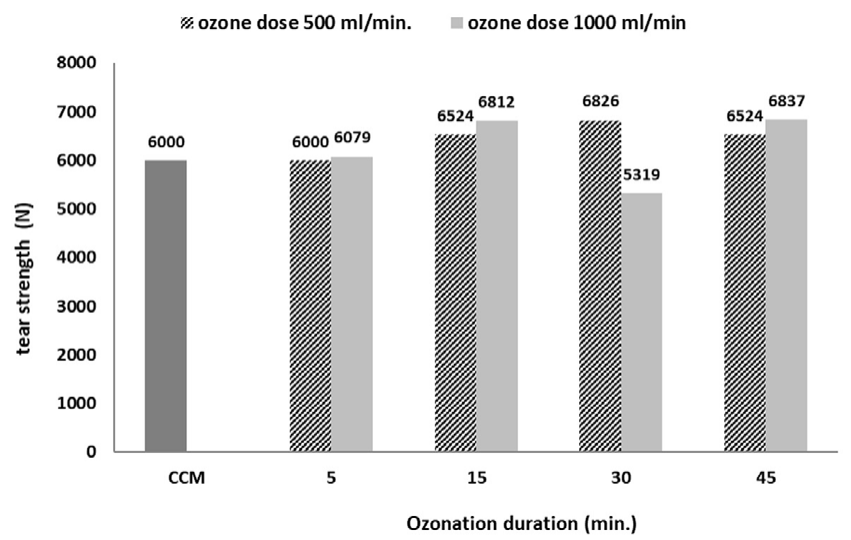

Figure 10: Tear strength of fabric having $500 \mathrm{gr} / \mathrm{m}^{2}$ areal weight. (CCM: Combined conventional desizing and scouring method).

\begin{tabular}{|c|c|c|c|c|c|c|c|c|c|c|c|}
\hline \multirow{2}{*}{$\begin{array}{c}\text { Fabric areal } \\
\text { density }\left(\mathrm{gr} / \mathrm{m}^{2}\right)\end{array}$} & \multirow{2}{*}{$\begin{array}{l}\text { Pile yarn length } \\
\text { (cm/10 cm })\end{array}$} & \multicolumn{10}{|c|}{ Weight losses for different cycles of abrasion test (gr) } \\
\hline & & 1000 & 5000 & 11000 & 15000 & 20000 & 25000 & 30000 & 35000 & 40000 & 45000 \\
\hline 350 & 43.63 & 0.01 & 0.01 & 0.02 & 0.03 & 0.03 & 0.03 & 0.04 & 0.06 & 0.07 & 0.08 \\
\hline 400 & 53.45 & 0.00 & 0.01 & 0.01 & 0.02 & 0.02 & 0.02 & 0.03 & 0.03 & 0.04 & 0.05 \\
\hline 450 & 67.66 & 0.01 & 0.01 & 0.02 & 0.03 & 0.03 & 0.05 & 0.05 & 0.06 & 0.07 & 0.07 \\
\hline 500 & 76.15 & 0.01 & 0.01 & 0.02 & 0.02 & 0.03 & 0.03 & 0.03 & 0.04 & 0.05 & 0.06 \\
\hline
\end{tabular}

Table 5: The weight losses of terry fabrics treated by combined conventional desizing and scouring process (CCM) after abrasion test.

ozone desizing process conditions, when the pile yarn length increases, the weight loss of the terry fabrics increases.

- Finally, it can be said that although the weight loss of the terry fabric with the longest pile yarn is more than those of the other fabrics, there is no break on the surface of this fabric samples even at the highest cycle.

After the terry fabrics were treated by combined conventional desizing and scouring, they were tested by the same abrasion method and the same device. The results are presented in below Table 5 [17].

When the table is evaluated:

- It is found that when the number of cycle in abrasion test increases, the weight loss of terry fabrics increase,

- It is deduced that there is no a linear relationship between the changing of pile yarn length and the weight loss.

- It is seen that for the same abrasion cycles, the weight losses of fabric treated by CCM are lower than those of the fabrics treated by ozone desizing process.

- It can be said as the most remarkable result that while some fabric samples breaks at the cycle of 20000 , none of the samples breaks at the highest cycle, 40000 .

\section{Conclusion}

The following results can be deduced from the evaluating introduced above. The most factors effecting tear strength of terry fabrics treated by ozone desizing process are ozone dose and ozonation duration. The effect of ozone dose on tear strength is more marked than those of the factors such as ozonation duration and pile length. In the contrary, the effect of pile yarn length is more evident for terry fabrics treated combined conventional desizing process. After this process, when the pile yarn length decreases, the strength decreases.

In ozonation desizing process, ozonation duration and ozone dose influence on the abrasion resistance of terry fabrics, but the relation between these properties of ozonation process and abrasion resistance is not linear. In the combined conventional desizing, the pile yarn length and abrasion cycle have an important effect on this property.

Additionally, when the decreasing of tear strength and abrasion resistance belonging to both methods are compared with each other, it can be said that the combined conventional desizing and scouring process damage the fabric less than the ozonation process.

The application of the combined conventional desizing method is original study. There is no adequate study about the effect of this method on the properties of the cotton fabrics, especially terry fabrics. Additionally, there isn't any study about the investigation of the effect of ozone desizing process on the properties of the terry cotton fabrics. So, in the future, it is suggested that the new and additional studies about these subjects should be carried out to clarify the relationships between some factors (ozonation duration, ozone dose, pile yarn length) and the properties of terry fabrics.

\section{Acknowledgements}

We would like to thank to Yünsa Worsted \& Woolen Production and Trading Co. (in Tekirdag, Turkey) because they provided us to make all of test in their laboratory and funded the publication charges. We would like to thank to Altinbasak Textile Company (in Denizli, Turkey) for providing woven terry fabrics samples. We would also like to thank to Prof. Dr. Huseyin Aksel EREN (at Uludag University, Department of Textile Engineering in Bursa) for providing the using of Ozone Generator.

\section{References}

1. Patil TC (2015) Terry Towels-Classification, Designing and Manufacturing Technology. International Journal on Textile Engineering and Processes Vol: 1.

2. Wasiak IF, Snycerski M (2004) Use Properties of Terry Woven Fabrics. Fibres Text East Eur 12: 45.

3. Sekerden F (2002) Effect of Pile Yarn Type On Absorbency, Stiffness, And Abrasion Resistance of Bamboo/Cotton and Cotton Terry Towels. Wood Fiber Sci 44: 189-195.

4. Swami NM, Hari PK, Anandjiwala R (1984) Performance properties of Terry 
Citation: Turhan Y, Soydas S (2018) The Effects of the Ozone Desizing and Combined Conventional Desizing and Scouring On Tear Strength and Abrasion Resistance of 100\% Cotton Terry Fabrics. J Textile Sci Eng 8: 353. doi: 10.4172/2165-8064.1000353

Towels Made from Open-end and Ring Spun Yarns. Indian J Text Res 9: 90-94.

5. Sekerden F (2015) A Comparative Analysis of Towels Produced from Twisted and Twistless Cotton Pile Yarns in Terms of Absorptive Capacity and Flexural Rigidity. J Eng Fibers Fabr 10: 201.

6. Tavčer PF (2013) Effects of Cellulose Enzyme Treatment on the Properties of Cotton Terry Fabrics. Fibres Text East Eur 6: 100-110.

7. Mojsov K (2017) Enzymatic Scouring and Bleaching of Cotton Terry FabricsOpportunity of The Improvement On Some Physicochemical and Mechanical Properties of the Fabrics. J Nat Fibers.

8. Bahtiyari I, Benli H (2016) Ozone Bleaching of Cotton Fabrics with the Aid of Ultrasonic Humidifier. Cellulose 23: 2715-2725.

9. Eren HA, Ozturk D (2010) The evaluation of ozonation as an environmentally friendly alternative for cotton preparation. Text Res J 81: 512-519.

10. Arooj F, Ahmad N, Shaikh IA and Chaudhry MN (2014) Application of ozone in cotton bleaching with multiple reuse of a water bath. Text Res J I 84: 527-538.

11. Prabaharan M, Venkata Rao J (2003) Combined desizing, scouring and bleaching of cotton using ozone. Indian Journal of Fibre and textile Research 28: $437-443$
12. Piccoli HH, Souza Aau, Smagu S (2015) Bleaching of Knitted Cotton Fabric Applying Ozone. Ozone: Sci Eng 37: 170-177.

13. Prabaharan M, Venkata Rao J (2001) Study on ozone bleaching of cotton fabric-process optimization, dyeing and finishing properties. Color Technol 117: 98-103.

14. Hmida SB, Ladhari N (2016) Study of Parameters Affecting Dry and Wet Ozone Bleaching of Denim Fabric. Ozone. The Journal of the International Ozone Association 38: 175-180.

15. Eren HA, Aniş P, Yilmaz D, Kirişçi S, İnkaya T (2009) Combined Use of Laccase, Ozone and Hydrogen Peroxide for Cotton Bleaching. Tekstil Ve Konfeksiyon 4: 299-303.

16. Perincek S, Bahtiyari I, Korlu A, Duran K (2009) New Techniques in Cotton Finishing.Text Res J 79: 121-128.

17. Soydas S (2016) An Investigation of Ozone Technology Impact On Woven Towel Fabrics in The Hydrophilite and Bleaching Feature. Pamukkale University, Institute of Science, Textile Engineering Department, Master of Science Thesis.

18. www.spot.com.tr (2017) Turkish Catalog of TANA®ZYM NCP 